\title{
Overexpression of Rice (Oryza sativa L.) OsCDR1 Leads to Constitutive Activation of Defense Responses in Rice and Arabidopsis
}

\author{
Bishun Deo Prasad, ${ }^{1}$ Gary Creissen, ${ }^{2}$ Chris Lamb, ${ }^{2}$ and Bharat B. Chattoo \\ ${ }^{1}$ Genome Research Centre, Department of Microbiology and Biotechnology Centre, Faculty of Science, The M. S. University \\ of Baroda, Vadodara, Gujarat-390002, India; ${ }^{2} J o h n$ Innes Centre, Norwich Research Park, Colney, Norwich NR4 7UH, U.K.
}

Submitted 11 May 2009. Accepted 28 July 2009.

\begin{abstract}
Plant aspartic proteases (AP) play key roles in the regulation of biological processes, such as the recognition of pathogens and pests and the induction of effective defense responses. $A$ large number of AP (>400) have been identified in silico in the rice genome. None have previously been isolated and functionally characterized for their involvement in disease resistance. We describe here the isolation and characterization of a gene $(O s C D R 1)$ from rice which encodes a predicted aspartate protease. Expression of $O s C D R 1$ was activated upon treatments with benzothiadiazole and salicylic acid, which are signal molecules in plant disease resistance responses. Ectopic expression of $O s C D R 1$ in Arabidopsis and rice conferred enhanced resistance against bacterial and fungal pathogens. The enhanced disease resistance observed in transgenic plants was correlated with induction of pathogenesis-related gene expression and was shown by mutational analysis to be dependent on AP activity of the transgene-encoded product. OsCDR1 accumulates in intercellular fluids (IF) in transgenic plants. Infiltration of IF from transgenic Arabidopsis plants into leaves of wild-type (WT) Arabidopsis induced the systemic defense response. These results demonstrate the conservation of CDR1 function between rice and Arabidopsis during the disease resistance response.
\end{abstract}

Plants use complex recognition and response mechanisms to protect themselves from pathogen attack. Major resistance $(R)$ genes specify recognition of pathogens carrying the corresponding avirulence (Avr) genes, leading to the rapid activation of a battery of inducible defense mechanisms, including reinforcements of the cell wall, synthesis of antimicrobial compounds, and deployment of pathogenesis-related (PR) proteins (Yang et al. 1997; Dangl and Jones 2001). This induced defense is often accompanied by the collapse of challenged plant cells in the specific area showing hypersensitive response (HR), which results from localized cell death to restrict the pathogen at the site of pathogen attack. Some of the effector mechanisms contribute to basal resistance which underpins attempted disease lesion limitation triggered by pathogen-associated molecular patterns (PAMPs) in the absence of $R$-gene-

Professor Chris Lamb passed away on August 21, 2009.

Corresponding author: B. B. Chattoo; Telephone : +91-265-2794396; Fax: +91-265-2792508; E-mail: bharat.chattoo@bcmsu.ac.in

* The $e$-Xtra logo stands for "electronic extra" and indicates that four supplementary figures are published online and also that Figure 5 appears in color online. mediated recognition (Grant and Lamb 2006). A third type of resistance is salicylate (SA)-associated defense (Durrant and Dong 2004), in which local attack by a necrotizing pathogen induces broad-spectrum resistance throughout the plant system against an array of pathogens (Grant and Lamb 2006).

In dicots, several regulatory proteins have been implicated in the transcriptional regulation of defense genes under the control of the SA signaling pathway. The key regulator of SA-mediated resistance, $N P R 1$, is functionally conserved in diverse plant species, including rice (Oryza sativa L.), which demonstrates that rice has evolved an SA-mediated systemic acquired resistance (SAR) similar to that in Arabidopsis. Improved understanding of basal, acquired, and nonhost resistance mechanisms, primarily from studies in Arabidopsis, together with demonstrated or anticipated convergence of gene function between monocots and dicots provide an exciting avenue to gain better insights into these resistance mechanisms in rice.

Recently, several proteases have been found to play important roles in plant-microbe interactions. Several Avr genes that encode different classes of proteases have been identified (Jia et al. 2000; Orth et al. 2000; Shao et al. 2002). Aspartic proteases (AP), one of the main proteinase classes, play key roles in the regulation of biological processes, including responses to pathogens and pests and the induction of effective defenses (Domsalla and Melzig 2008). The biological functions of plant AP are poorly understood and, for the great majority of plant AP, the biological functions are still hypothetical. In general, plant AP have been implicated in protein processing or degradation in different plant organs, as well as in plant senescence, stress responses, programmed cell death, and reproduction (Simoes and Faro 2004).

Arabidopsis constitutive disease resistance 1 (CDR1) is a member of the larger group of the atypical AP and was identified in a screen for gain-of-function mutants displaying enhanced resistance to bacterial pathogens following T-DNA activation tagging (Weigel et al. 2000; Xia et al. 2004). Overexpression of CDRl mimics constitutive activation of SAR, including the accumulation of high levels of SA and transcripts of SAR marker genes such as PRI and PR2. The enhanced resistance of the $C D R 1$ gain-of-function mutant is likely due to the proteolytic generation of an endogenous peptide elicitor, which might be involved in the activation of SA-dependent local and systemic defense responses (Xia et al. 2004).

Similar to Arabidopsis, a large number of AP (>400) have been identified in silico in the rice genome (MEROPS peptidase database). None have previously been isolated and functionally characterized for their involvement in disease resistance. To understand the role of AP in rice disease resistance, we 
isolated the rice ortholog OsCDR1 (GenBank accession number NP_001042193) using published data on the Arabidopsis CDR1 (Xia et al. 2004). Here, we report that OsCDR1 is an apoplastlocalized protein and AP activity is essential for its biological function. Further, ectopic expression of $O s C D R 1$ in Arabidopsis and rice led to increased expression of defense-related genes and enhanced disease resistance against bacterial and fungal pathogens, indicating the presence of a similar defense pathway in both species.

\section{RESULTS}

\section{Identification of a rice CDR1 homologue.}

BLASTP searches were performed using the complete protein sequence of Arabidopsis CDR1 (AtCDR1) as the query sequence. From the 50 highest-scoring alignments, the $28 \mathrm{Arabi}$ dopsis and rice sequences were used to create a phylogenetic tree which identified a single rice sequence (gi|115434870|) that fell within the same clade as AtCDR1 (Fig. 1A). This single OsCDR1 ortholog had 50\% similarity and 36\% identity with AtCDR1 at the amino acid level.

The genomic sequence of $O s C D R l$, like $A t C D R l$, has no intron. It contains a predicted open reading frame of $1,362 \mathrm{bp}$, encoding a protein of 454 amino acid residues with a calculated molecular weight of $45.91 \mathrm{kDa}$ that is predicted to be extracellular by the PSORT algorithm (Nakai and Kanehisa 1992), with a signal peptide cleaved between positions 21 and 22. Like other eukaryotic AP of the pepsin family, OsCDR1 contains two catalytic aspartic acid residues within two conserved active sites with the sequence motif Asp-Thr/Ser-GlySer/Thr (Fig. 1B).

\section{Responses of $O s C D R 1$ to chemical treatment.}

Quantitative real-time reverse-transcriptase (RT) polymerase chain reaction (qPCR) analysis showed that induced expression of OsCDRl occurred as early as $6 \mathrm{~h}$ after treatment with SA or with the SA analogue, benzothiadiazole (BTH); peaked at $12 \mathrm{~h}$ after treatment; and declined thereafter (Fig. 2). There was no increased transcription of $O s C D R l$ after treatment with jasmonic acid (JA).

\section{Generation and characterization of transgenic plants.}

To gain further information on the biological function of OsCDR1, transgenic Arabidopsis and rice lines were produced that ectopically expressed $O s C D R I$ under the control of a double Cauliflower mosaic virus $35 \mathrm{~S}$ promoter. Representative homozygous $\mathrm{T}_{3}$ transgenic Arabidopsis lines (At3, At6, At8, and At17) and homozygous $\mathrm{T}_{2}$ rice lines (R2, R6, R10, and $\mathrm{R} 11)$ that displayed varying levels of expression of $O s C D R 1$ (Fig. 3A) were used in this study. Protein gel-blot analysis using antibodies raised against an OsCDR1 peptide detected a single polypeptide with an approximate size of $49 \mathrm{kDa}$ in the transgenic lines. The experimentally determined size of plant-expressed OsCDR1 is greater than the size calculated from its open reading frame $(45.91 \mathrm{kDa})$, indicating that the mature OsCDR1 protein might be post-translationally modified. As expected, different transformed lines displayed different levels of OsCDR1 protein (Fig. 3B).

\section{OsCDR1 is an extracellular protein.}

Based on the presence of an N-terminal signal sequence, OsCDR1 was predicted to be an extracellular protein. Protein gel-blot analysis indicated that there was substantial enrichment of OsCDR1 in intercellular fluids (IF) from transgenic Arabidopsis plants. Similar signals were obtained on protein gel blots of total and IF extracts despite there being approximately 25 times more protein in the crude extract (Supplemen- tary Fig. 1). Furthermore, immunolocalization of OsCDR1 in tissue sections of transgenic rice leaf tissue showed strong immunofluorescence in the intercellular spaces associated with the cell wall, whereas no immunofluorescence was detected in the wild-type (WT) leaf (Supplementary Fig. 2), further supporting an extracellular location for OsCDR1.

\section{Transgenic plants have elevated levels of $\mathrm{SA}$ and increased generation of $\mathrm{H}_{2} \mathrm{O}_{2}$.}

To assess possible effects of overexpressing OsCDRI on SA accumulation, we measured SA in transgenic lines and the WT. The level of SA was approximately 11-fold higher in transgenic Arabidopsis and approximately 1.3-fold higher in transgenic rice compared with the WT. Because SA treatments enhanced $\mathrm{H}_{2} \mathrm{O}_{2}$ levels in plants (Chen et al. 1993b), we performed diaminobenzidine (DAB) staining which revealed accumulation of $\mathrm{H}_{2} \mathrm{O}_{2}$ in OsCDR1-expressing Arabidopsis and rice lines (Supplementary Fig. 3). Previously, $\mathrm{H}_{2} \mathrm{O}_{2}$ or active oxygen has been shown to be an important pathogen signal in plants (Alvarez et al. 1998).

\section{Overexpression of $O s C D R 1$ in Arabidopsis results in increased expression of defense-related genes.}

SA accumulation has been shown to be a requirement for the induction of $P R$ gene expression and the establishment of SAR in tobacco and Arabidopsis (Gaffney et al. 1993; Delaney et al. 1994). Because elevated levels of SA were detected in transgenic plants, we examined the expression of $P R$ genes in OsCDR1:Arabidopsis lines. qPCR analysis showed that the transcript levels of both $P R I$ and $P R 2$ were upregulated to varying levels in transgenic Arabidopsis lines in the absence of the pathogen (Fig. 4A and B). The $P R 1$ and $P R 2$ transcripts were more than 300-fold higher in the uninfected At17 line than in the equivalent healthy WT. In contrast, PDF1.2 transcripts, encoding a defensin protein that is induced in Arabidopsis by an SA-independent pathway involving JA (Penninckx et al. 1996), were not elevated in uninfected OsCDR1:Arabidopsis plants, indicating the activation of SA-dependent responses.

\section{Responses of $O S P R 1$ genes in transgenic rice.}

We examined whether overexpression of the $O s C D R 1$ gene in rice enhanced the expression of defense genes $P B Z 1$ (probenazole-inducible gene)/PRIO and PRla by qPCR. The transcript levels of $P B Z 1$ and PRIa were $23.45 \pm 4.99$ - to $41.35 \pm$ 3.87 - and $68.26 \pm 2.05$ - to $133.73 \pm 4.81$-fold higher, respectively, in uninfected transgenic rice lines compared with that in the WT (Fig. 4C and D). Additionally, the expression patterns of each of the 12 OsPRI genes was analyzed by qPCR using specific primers described previously (Mitsuhara et al. 2008). The transcript levels of the SA-, JA-, and 1-aminocyclopropane-1-carboxylic acid (ACC)-inducible genes OsPRI\#012, OsPR1\#051, OsPR1\#074, and OsPR1\#101, as well as those of the SA-inducible genes OsPRI\#011 and OsPRI\#052 (Mitsuhara et al. 2008), were higher in uninfected rice line R6 compared with those of the WT (Fig. 4E). There was, however, no increase in transcription of OsPR1\#071, OsPR1\#073, and OsPRI\#121, which are upregulated by JA but not by SA (Fig. 4E). These results suggest that $O S C D R 1$ is likely to be involved in basal defense against pathogens in a manner that is dependent on SA but independent of JA and ACC signaling.

\section{Overexpression of OsCDR1 in Arabidopsis confers enhanced disease resistance to Pseudomonas syringae and Hyaloperonospora arabidopsidis.}

The similarity between $A t C D R 1$ and $O s C D R 1$ prompted us to test the response of OsCDRl overexpressing Arabidopsis plants to pathogen challenge. When challenged with Pseudo monas syringae pv. tomato DC3000, OsCDR1:Arabidopsis 


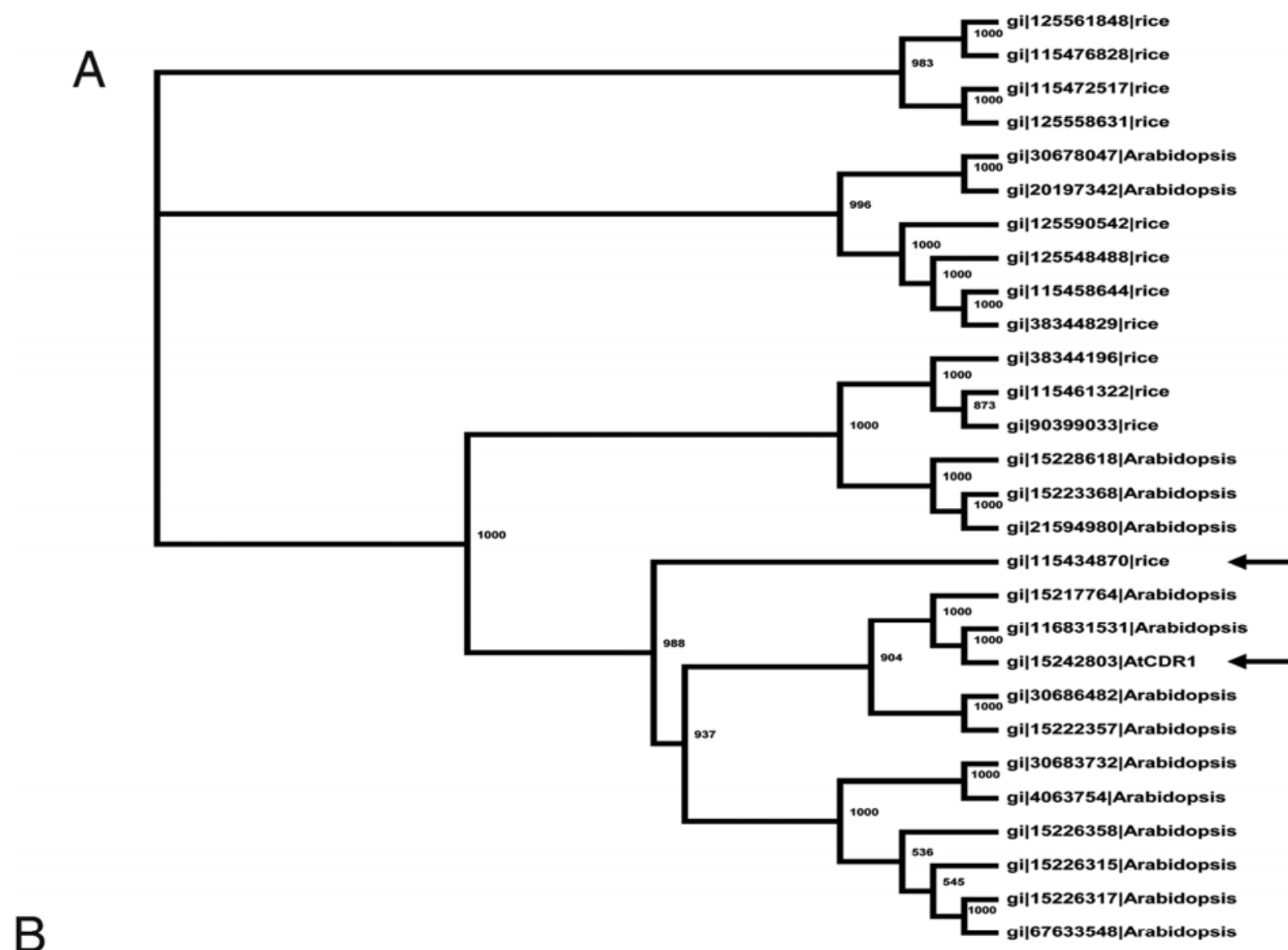

gi|15242803|Arabidopsis gi|115434870|rice

gi|15242803|Arabidopsis gi|115434870|rice

gi|15242803|Arabidopsis gi|115434870|rice

gi|15242803|Arabidopsis gi|115434870|rice

gi|15242803|Arabidopsis gi|115434870|rice

gi|15242803|Arabidopsis gi|115434870|rice

gi|15242803|Arabidopsis gil115434870|rice

gi|15242803|Arabidopsis gil115434870|rice

gi|15242803|Arabidopsis gi|115434870|rice

gi|15242803|Arabidopsis gi|115434870|rice
MASLFSS---VLLSLCLLSSLFLSNANAKPKLGFTADLIHRDSPKSPFYN 47 MAAMAPSSVLVLLGVVLLVAGGRLCECAASGGGFSVEFIHRDSPRSPFHD 50

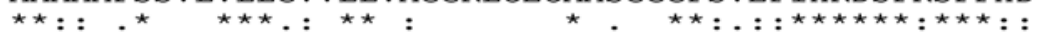

PMETSSQRLRNAIHRSVNRVFHFTEKDNTPQPQ--------IDLTSNSGE 89 PAFTAHGRALAAARRSVARAAAIAGSASSSASGGGAADDVVSKVVSRSFE 100

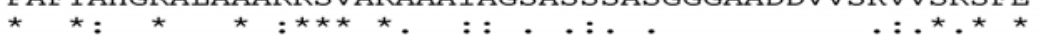

YLMNVSIGTPPFPIMAIADTGSDLLWTQCAP-CDDCYTQVDP--LFDPKT 136 YLMTVNLGSPPRSMLAIADTGSDLVWVKCKKGNNDTSSAAAPTTQFDPSR 150

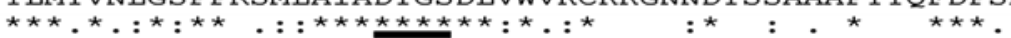

SSTYKDVSCSSSQCTALENQASCSTNDNTCSYSLSYGDNSYTKGNIAVDT 186 SSTYGRVSCQTDACEALG-RATCDDGSN-CAYLYAYGDGSNTTGVLSTET 198

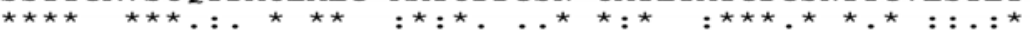

LTL--GSSDTRPMQLKN--IIIGCGHNNAGTFNKKGSGIVGLGGGPVSLI 232 FTFDDGGSGRSPRQVRVGGVKFGCSTATAGSFP--ADGLVGLGGGAVSLV 246

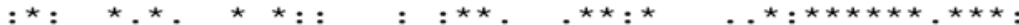

KQLG--DSIDGKFSYCLVPLTSKKDQTSKINFGTNAIVSGSGVVSTPLIA 280 TQLGGATSLGRRFSYCLVPHSVN--ASSALNFGALADVTEPGAASTPLVA 294

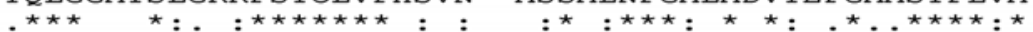

KASQETFYYLTLKSISVGSKQIQYSGSDSESSEGNIIIDSGTTLTLLPTE 330 G-DVDTYYTVVLDSVKVGNKTVASAASSR------IIVDSGTTLTFLDPS 337

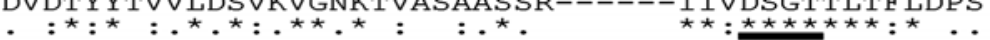

FYSELEDAVASSIDAEKKQDPQSGLSLCYSATG-----DLKVPVITMHFD 375 LLGPIVDELSRRITLPPVOSPDGLLOLCYNVAGREVEAGESIPDLTLEFG 387

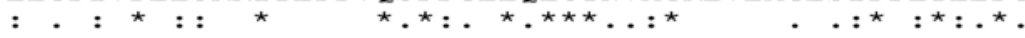

G-ADVKLDSSNAFVQVSEDLVCFAFRGSP---SFSIYGNVAQMNFLVGYD 421 GGAAVALKPENAFVAVQEGTLCLAIVATTEQQPVSILGNLAQQNIHVGYD 437

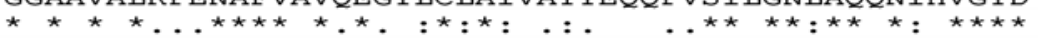

TVSKTVSFKPTDCAKM- 437 LDAGTVTFAGADCAGSS 454

$$
: \star \star: \star \quad: \star \star \star
$$

Fig. 1. Relationship of Arabidopsis CDR1 (AtCDR1) with related proteins from Arabidopsis and rice. A, Phylogenetic tree was generated by the neighborjoining method using Clustal X version 1.81. Sources of the genes are indicated. Bootstrap values (shown at the corresponding nodes) were obtained from 1,000 replicates and are reported as percentages. B, Amino acid sequence alignment of AtCDR1 and OsCDR1 using ClustalW. The two conserved catalytic sites are underlined. 
supported up to six times less bacterial growth at 2 days post inoculation (dpi) compared with the WT (Fig. 5A). Further, measurement of bacterial titers after 4 dpi indicated that the bacterial population in transgenic Arabidopsis lines At8 and At17 leaves were reduced by at least 6- and 10-fold, respectively, compared with that in the WT.

Transgenic Arabidopsis lines were further evaluated for disease resistance by the virulent Noco2 isolate of Hyaloperonospora arabidopsidis. Compared with the WT, transgenic Arabidopsis plants supported up to 10 times less fungal conidia at 5 dpi (Fig. 5B). These results suggest that ectopic expression of OsCDR1 in transgenic Arabidopsis confers disease resistance against $P$. syringae and $H$. arabidopsidis.

\section{Susceptibility of transgenic Arabidopsis lines to Alternaria brassicicola.}

The disease resistance phenotype of OsCDR1:Arabidopsis plants against Alternaria brassicicola, a necrotrophic fungal pathogen, was also examined. The lengths of lesions were 2.87 $\pm 0.85 \mathrm{~mm}$ in the inoculated WT, whereas they ranged from $3.13 \pm 0.16$ to $7.0 \pm 0.16 \mathrm{~mm}$ in the four transgenic lines (Fig. 5C). Lesion lengths in the At17 transgenic plants were significantly higher than that observed in WT plants, whereas there was no significant difference between the other transgenic lines and the WT.

\section{Overexpression of $O S C D R 1$ in rice confers enhanced disease resistance}

to Xanthomonas oryzae and Magnaporthe oryzae.

In order to evaluate the range of protection offered by overexpression of $O s C D R 1$ in rice, we examined selected trans-

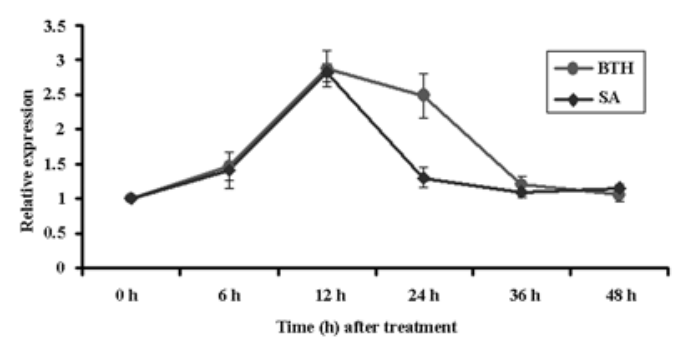

Fig. 2. OsCDR1 transcripts following benzothiadiazole (BTH) and salicylate (SA) treatments. Rice seedlings were treated with $0.3 \mathrm{mM} \mathrm{BTH}$ or 3 $\mathrm{mM}$ sodium salicylate. Leaf samples were collected at the indicated time points. Transcript levels were analyzed by quantitative polymerase chain reaction and are expressed relative to the mock treatment at each time point. Bars indicate mean \pm standard deviation.

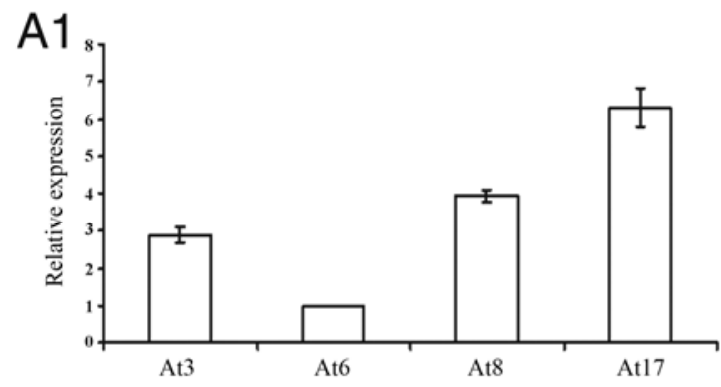

B1

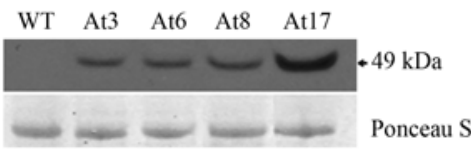

formed lines for resistance against rice blast fungus Magnaporthe oryzae and the bacterial blight pathogen Xanthomonas oryzae. Following inoculation with $X$. oryzae, the WT plants showed a large diseased area compared with the transgenic lines at $12 \mathrm{dpi}$. The length of diseased area ranged from $0.90 \pm$ 0.20 to $1.43 \pm 0.31 \mathrm{~cm}$ in transgenic rice lines compared with $3.4 \pm 0.50 \mathrm{~cm}$ in the inoculated WT (Fig. 5D).

Further, the transgenic rice lines were evaluated for disease resistance to the blast fungus.

The severity of infection in transgenic plants at 10 dpi was considerably lower than that observed in the WT. The percent diseased leaf area in the four transgenic lines ranged from $21.33 \pm 2.08$ to $26.33 \pm 0.50 \%$ compared with $82.67 \pm 1.53 \%$ in the WT plants (Fig. 5E). These results indicate that overexpression of $O s C D R I$ in transgenic rice enhances disease resistance against both $X$. oryzae and $M$. oryzae, two major phytopathogens of rice worldwide.

\section{Protease activity is required for OsCDR1 function.}

To determine whether the AP activity of OsCDR1 was essential for its biological activity, two mutations were made by site-directed mutagenesis (as described below), and these were reintroduced into WT Arabidopsis. Unlike plants overexpressing WT OsCDR1, plants expressing D119N, where the mutation is in the active site, did not show the expression of $P R$ genes. In contrast, plants expressing D233N (where mutation is in aspartate residue away from the active site) showed expression of $P R$ genes comparable with that observed in $O s C D R 1$ transgenic Arabidopsis plants (Fig. 6). D119N and D233N overexpressing Arabidopsis plants were also analyzed for the expression of $P R 1$ and $P R 2$ gene by qPCR analysis. The expression of $P R 1$ and $P R 2$ genes in D233N-overexpressing Arabidopsis plants was 88- and 128-fold higher than that of the WT plant, whereas the D119N-overexpressing Arabidopsis plant did not show any induction of $P R$ genes. These results indicated that the AP activity of OsCDR1 is essential for $P R$ gene expression.

\section{Elicitor activity of OsCDR1.}

In order to determine the elicitor activity of OsCDR1, IF were isolated from 2-week-old transgenic Arabidopsis (At17) and WT plants grown in liquid Murashige and Skoog (MS) medium. High levels of $P R 2$ transcripts were observed in WT Arabidopsis plants when infiltrated with crude IF, a high molecular weight $(\mathrm{HMW})$ fraction $(>10 \mathrm{kDa})$ or a low molecular weight (LMW) fraction (3 to $10 \mathrm{kDa}$ ) of OsCDR1:Arabidopsis plants, whereas protein gel-blot analysis showed the presence of OsCDR1 protein in crude IF and HMW fractions (>10 kDa)

A2

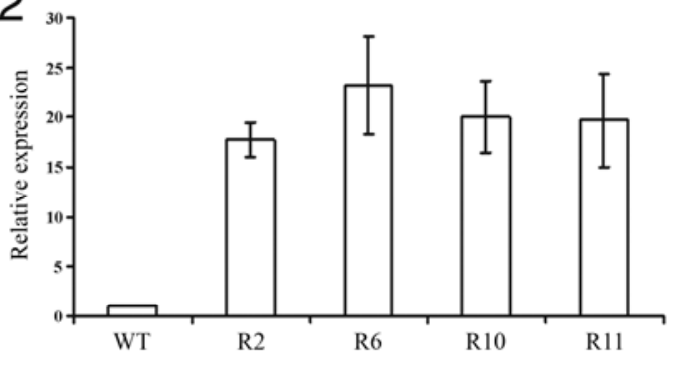

B2

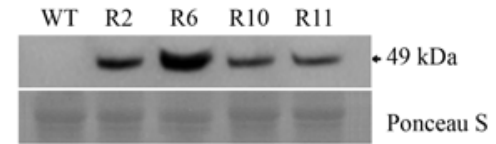

Fig. 3. Expression of $O s C D R 1$ in transgenic plants. A1, OsCDR1:Arabidopsis lines. Expression levels were presented relative to transgenic line At6. A2, OsCDR1:rice lines. Expression levels were compared with the wild type (WT). Protein-gel blot analysis of B1, OsCDR1: Arabidopsis lines and B2, OsCDR1:rice lines. Ponceau S staining of the membrane shows equal loading. Bars indicate mean \pm standard deviation. 
only (Fig. 7). No increase in transcript of $P R 2$ was observed when infiltrated with $<3-\mathrm{kDa}$ IF. Further, qPCR analysis showed that crude Ifs and HMW and LMW fractions induced $P R 2$ transcripts in both primary and systemic secondary leaves at 12 and $24 \mathrm{~h}$ of infiltration. The LMW fraction, which does not contain OsCDR1 protein, also induced $P R 2$ transcripts in both the primary and secondary leaves. The response in distant tissues to local inoculation with the LMW fraction was comparable with the distant effects of local inoculation with the HMW fraction, suggesting that the elicitor activity in the LMW fraction makes a substantial contribution to the systemic effects of OsCDR1 activity. Size fractionation analysis of IF demonstrated that the elicitor activity in the LMW fraction is associated with molecules in the 3- to $10-\mathrm{kDa}$ range.

\section{Phenotypic and agronomic characteristics of transgenic plants.}

Transgenic plants were further examined for their phenotype. Transgenic Arabidopsis lines At3, At6, and At8 appeared normal whereas line At17 showed growth retardation (Fig. 8). No overt growth or developmental differences were observed between the transgenic rice and WT plants in our experimental conditions. Further, transgenic rice lines were evaluated for percent germination, plant height, days for $50 \%$ flowering, and test weight. All four transgenic lines showed $100 \%$ germination, like the WT. Plant height in transgenics was 77.06 \pm 1.50 to $84.25 \pm 2.67 \mathrm{~cm}$, while it was found to be $85.12 \pm 1.02 \mathrm{~cm}$ in the WT (Supplementary Fig. 4A). Days required for $50 \%$ flowering ranged from $109.0 \pm 1.00$ to $128 \pm 3.02$ days in the case of transgenics whereas, in the WT, it was $108 \pm 2.00$ days. Test weight of transgenic seed ranged from $18.41 \pm 0.30$ to $19.61 \pm 0.25 \mathrm{~g}$ and was found to be $20.03 \pm 0.13 \mathrm{~g}$ in the case of the WT. Transgenic rice lines were comparable with the WT plants with respect to agronomic parameters critical from a breeder's point of view.

\section{DISCUSSION}

In this study, we explored the potential use of rice gene encoding an aspartate protease for the genetic engineering of enhanced resistance to a spectrum of diseases in rice and Arabidopsis. A large number of AP ( $>400)$ have been identified in silico in the rice genome (MEROPS peptidase database). However, their physiological roles are largely unknown. A rice CDR1 homologue (OsCDR1) was identified from a phylogenetic tree, generated by neighbor joining, using Arabidopsis CDR1 as bait. Our studies showed that $O s C D R 1$ was transcriptionally activated in response to treatments with BTH or SA but not with JA. Previous studies have demonstrated that $\mathrm{BTH}$ is effective in inducing disease resistance and in activating defense responses in rice (Gorlach et al. 1996; Xiong et al. 2001). Unlike most dicot plants, rice plants normally contain relatively high constitutive levels of free SA (Silverman et al. 1995). However, in spite of high endogenous levels, rice leaves have an SA-inducible glucosyl transferase activity (SA-GTase), an enzyme that conjugates SA (Silverman et al. 1995), suggesting that rice leaves can respond to exogenous SA. Whether SA is a signal molecule in rice disease resistance response has not been well established,

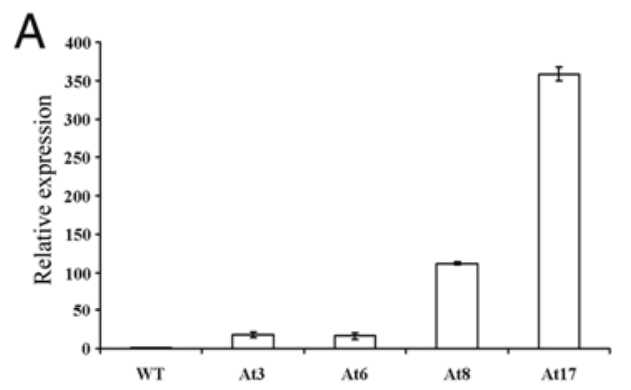

B
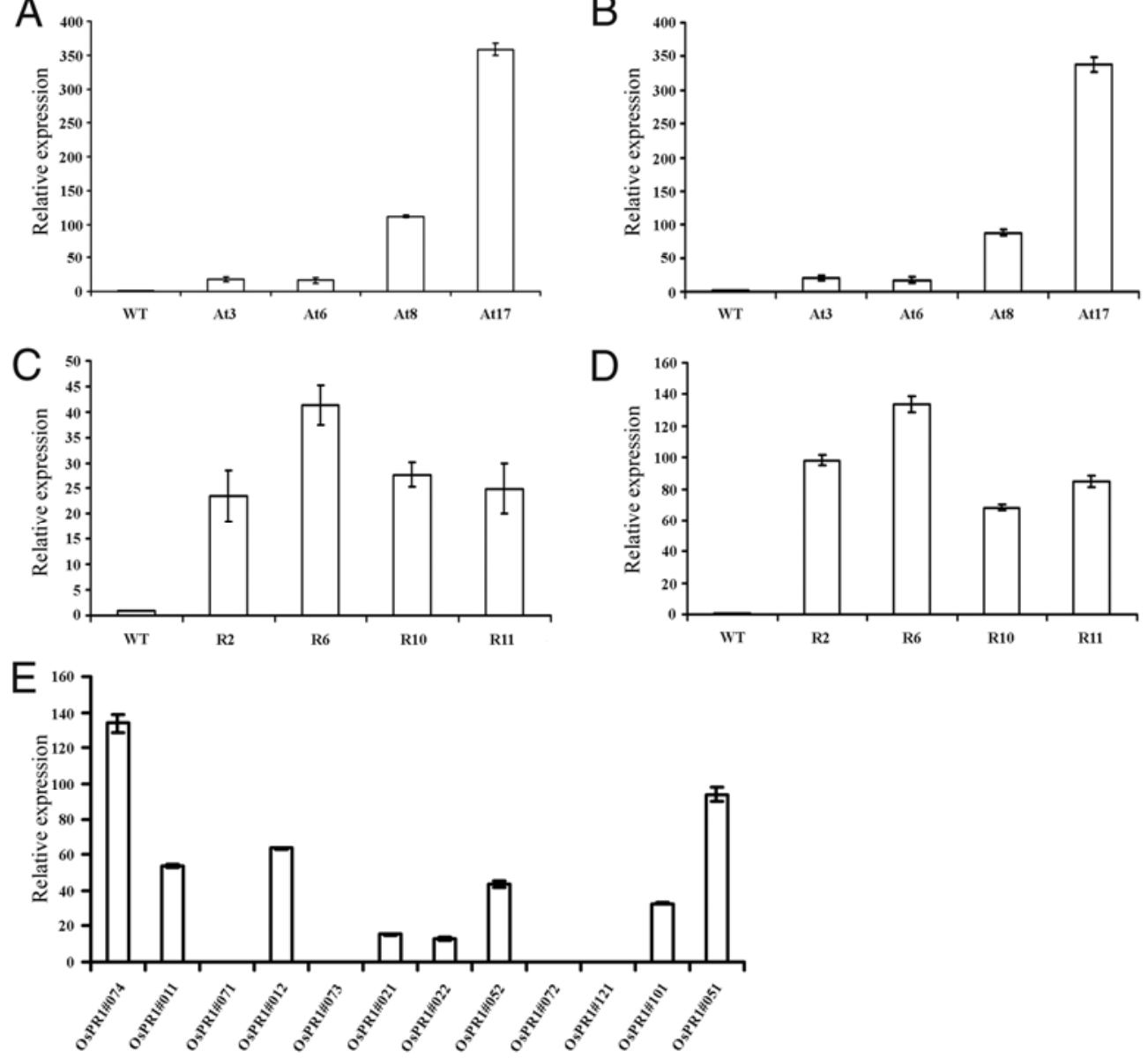

Fig. 4. Response of defense-related genes in transgenic plants by quantitative polymerase chain reaction analysis. Fold expression of $\mathbf{A}, P R 1$ and $\mathbf{B}, P R 2$ genes in transgenic Arabidopsis lines. Fold expression of C, PBZ1/PR10 and D, PRla in transgenic rice lines. E, Response of 12 OsPR1 genes in transgenic rice line R6 compared with the wild type (WT). Bars indicate mean \pm standard deviation. 
although exogenous application of SA to rice plants was found to induce various genes that play important roles in different stress responses (Xu et al. 2006; Li et al. 2008).

Functional validation of $O s C D R 1$ following identification through bioinformatics was achieved in transgenic Arabidopsis lines that ectopically expressed OsCDR1. Interestingly, OsCDR1:Arabidopsis accumulated high levels of SA and showed several-fold induction of the defense-related genes PR1 and PR2 but not of PDF1.2, a marker of JA-mediated responses. The accumulation of SA is an important step in the signal transduction pathway leading to SAR, disease resistance, and susceptibility (Delaney et al. 1994). It has been proposed that at least one of the mechanisms of SA effect is through upregulation of levels of active oxygen species such as $\mathrm{H}_{2} \mathrm{O}_{2}$ (Chen et al. 1993b). Leaves treated with SA have been shown to accumulate $\mathrm{H}_{2} \mathrm{O}_{2}$ in Arabidopsis and rice (Chen et al. 1993a, Ganesan and Thomas 2001). Interestingly, the transgenic plants also exhibited oxidative bursts leading to generation of $\mathrm{H}_{2} \mathrm{O}_{2}$ which have been previously shown to be associated with $P R l$ gene expression at a step in signal transduction upstream of SA (Bi et al. 1995). The high level of $P R$ gene expression in OsCDRl-transgenic plants suggests a role for OsCDRl in SA-mediated disease resistance signaling pathways. This is further supported by the observation that overexpression of $O s C D R 1$ in transgenic Arabidopsis plants enhanced resistance against infection by $P$. syringae and $H$. arabidopsidis but not against $A$. brassicicola. Both $P$. syringae and $H$.

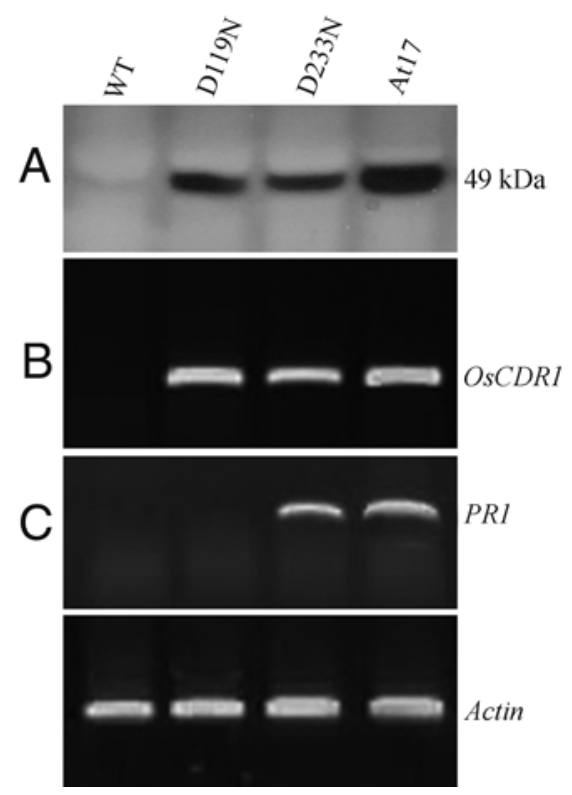

Fig. 6. OsCDR1 function requires aspartic protease activity. A, Immunodetection of OsCDR1; reverse-transcriptase polymerase chain reaction analysis of $\mathbf{B}, O s C D R 1$ and $\mathbf{C}, P R 1$ in Arabidopsis transformed with wildtype (WT) OsCDR1 or with mutated OsCDR1 in which either an active site aspartate (D119N) or a residue away from the active site (D233N) has been replaced by asparagine.
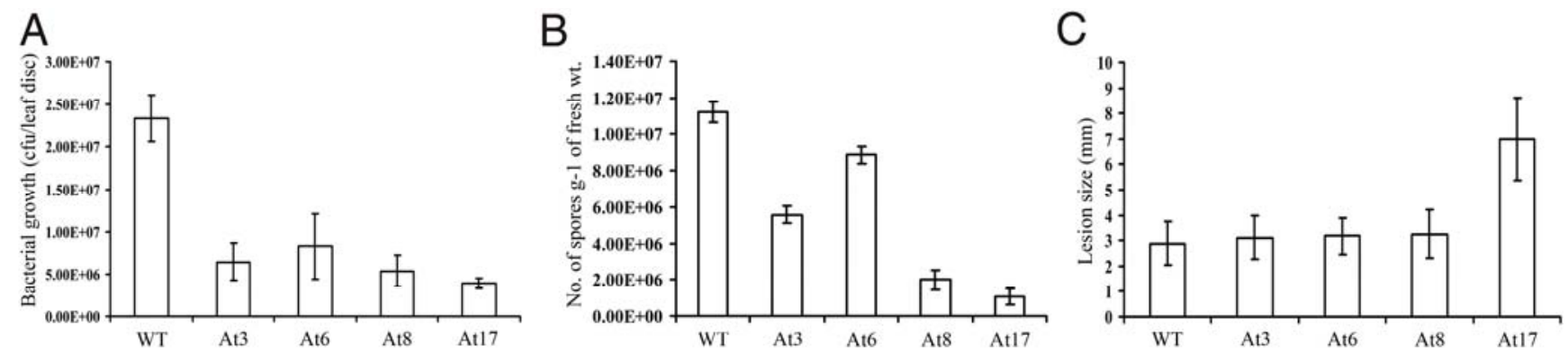

\section{D1}

D2

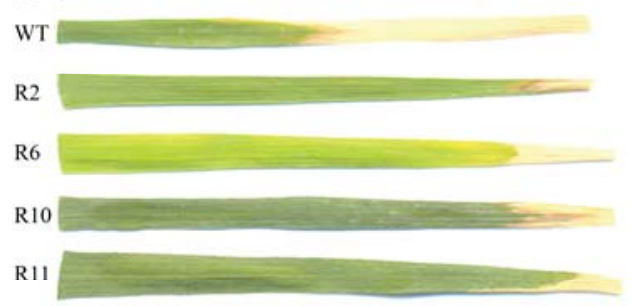

E1
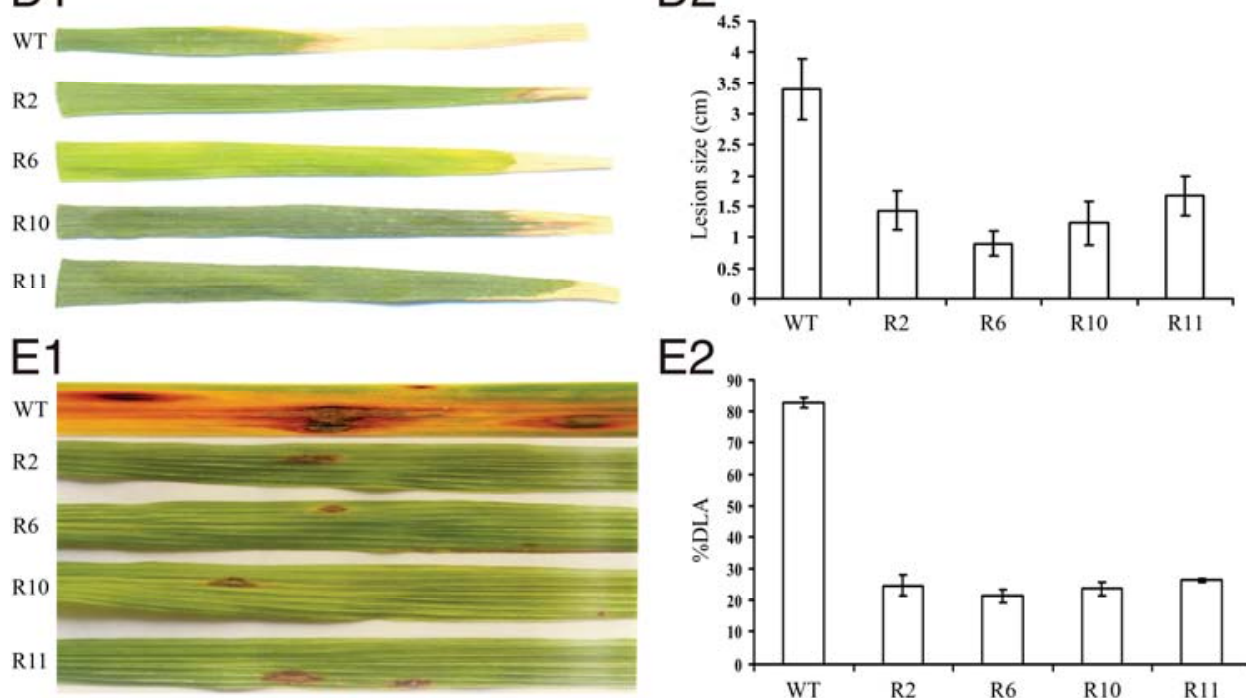

E2

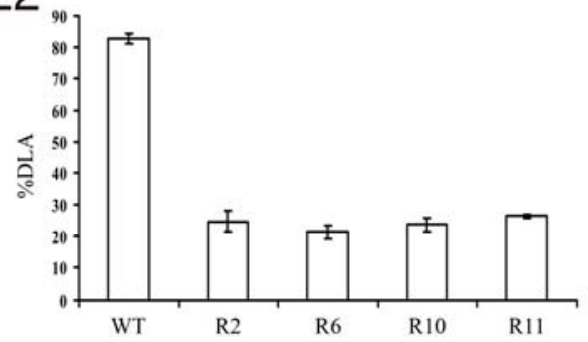

Fig. 5. Tests of transgenic plants for resistance to pathogens. A, Bacterial growth in leaves of wild-type (WT) and transgenic Arabidopsis lines infiltrated with virulent Pseudomonas syringae pv. tomato DC3000 was assayed at 2 days postinoculation (dpi). B, Number of conidia in leaves of WT and transgenic Arabidopsis lines inoculated with a conidial suspension of Hyaloperonospora arabidopsidis at 5 dpi. C, Disease severity in WT and transgenic Arabidopsis lines challenged with Alternaria brassicicola at 5 dpi. D1, Challenged transgenic rice lines showed resistance towards Xanthomonas oryzae in whole-plant infection assay in greenhouse. D2, Length of diseased area was measured at $12 \mathrm{dpi}$. E1, Challenged transgenic rice lines showed resistance toward blast disease in whole-plant infection assay in greenhouse. E2, Infected leaf area was measured as percent diseased leaf area (\%DLA) at 10 dpi. Bars represent mean \pm standard deviation. 
arabidopsidis have biotrophic phases of pathogenicity whereas A. brassicicola is a necrotrophic pathogen. Expression of $P R$ genes and the SA-dependent signaling pathway are involved in the regulation of defense responses against biotrophic pathogens, while the PDF1.2 gene and the JA and ethylene signaling pathway are involved in modulating defense responses against necrotrophic pathogens (Gupta et al. 2000; Kunkel and Brooks 2002; Spoel et al. 2003).

In Arabidopsis, overexpression of AtCDRl causes dwarfing (Xia et al. 2004) whereas, out of four transgenic lines studied, only one line (At17) showed growth retardation and an early leaf senescence phenotype. The leaf senescence phenotype observed in the At17 transgenic line might be due to higher expression of OsCDR1 or the nature of the T-DNA integration site.

OsCDR1 activation is likely to lead to the generation of an endogenous extracellular peptide elicitor, as has been proposed for Arabidopsis CDR1 (Xia et al. 2004). Indeed, local infiltration of IF from OsCDR1:Arabidopsis plants into WT Arabidopsis leaves induced the systemic defense response, and an elicitor activity was detected in the IF. The hypothesized elicitor released by OsCDR1 can rapidly activate basal defense responses in local and systemic leaves, suggesting a high capacity for mobility.

Further, evaluation and extension of this approach to the rice system is of high agronomical importance because rice is susceptible to a broad spectrum of diseases. Hence, transgenic rice plants overexpressing $O s C D R 1$ were generated and analyzed for the expression of various defense-related genes and for their resistance to $M$. oryzae and $X$. oryzae.

Expression of the different PR proteins is commonly used as a marker for SAR. Although activation of PR protein-encoding genes by compatible pathogens evidently does not lead to resistance in the plant against the invading pathogen, these genes may be effective if activated before the challenge inoculation occurs. In some cases, constitutive overexpression of $P R$ genes could further enhance resistance to certain pathogens (Jach et al. 1995; Epple et al. 1997). Hence, we overexpressed OsCDRI under a constitutive promoter which leads to activation of defense-related genes, including PBZ1/PRIO and PRI. Although variable levels of $O S C D R 1$ and defense-related genes were observed among the transgenic lines, there was a correlation between the levels of $O s C D R l$ and the degree of induction of defense-related genes. In rice, OsPRI genes are induced through the coordinated action of SA-, JA-, and ACCsignaling pathways and underlie the SAR response (Mitsuhara et al. 2008). Expression characteristics of the $12 \mathrm{OsPRl}$ genes indicate that the resistance obtained by $O S C D R 1$ :transgenic rice might be due to SA- but not JA- or ACC-mediated disease resistance signaling.

The fact that overexpression of OsCDRl in Arabidopsis and rice and previously reported CDRl in Arabidopsis showed elevated $P R$ gene expression and acquired enhanced resistance against phytopathogens suggests the presence of similar defense pathways in Arabidopsis and rice. It is important to note that overexpression of $O s C D R l$ in rice had no deleterious effects in our experimental conditions. This observation also satisfies the criteria of agricultural genetic engineering which include creating crops that are durable to stresses, require fewer chemical inputs, and do not show unwanted agronomic effects. These findings should greatly facilitate study on disease-resistance pathways in rice and other monocots, and may have a profound impact on controlling diseases in economically important crops such as cereals.

\section{MATERIALS AND METHODS}

Plant materials and treatments.

Arabidopsis thaliana ecotype Columbia (Col-0) plants were grown at $23^{\circ} \mathrm{C}$ under short-day conditions (9-h day length, 120
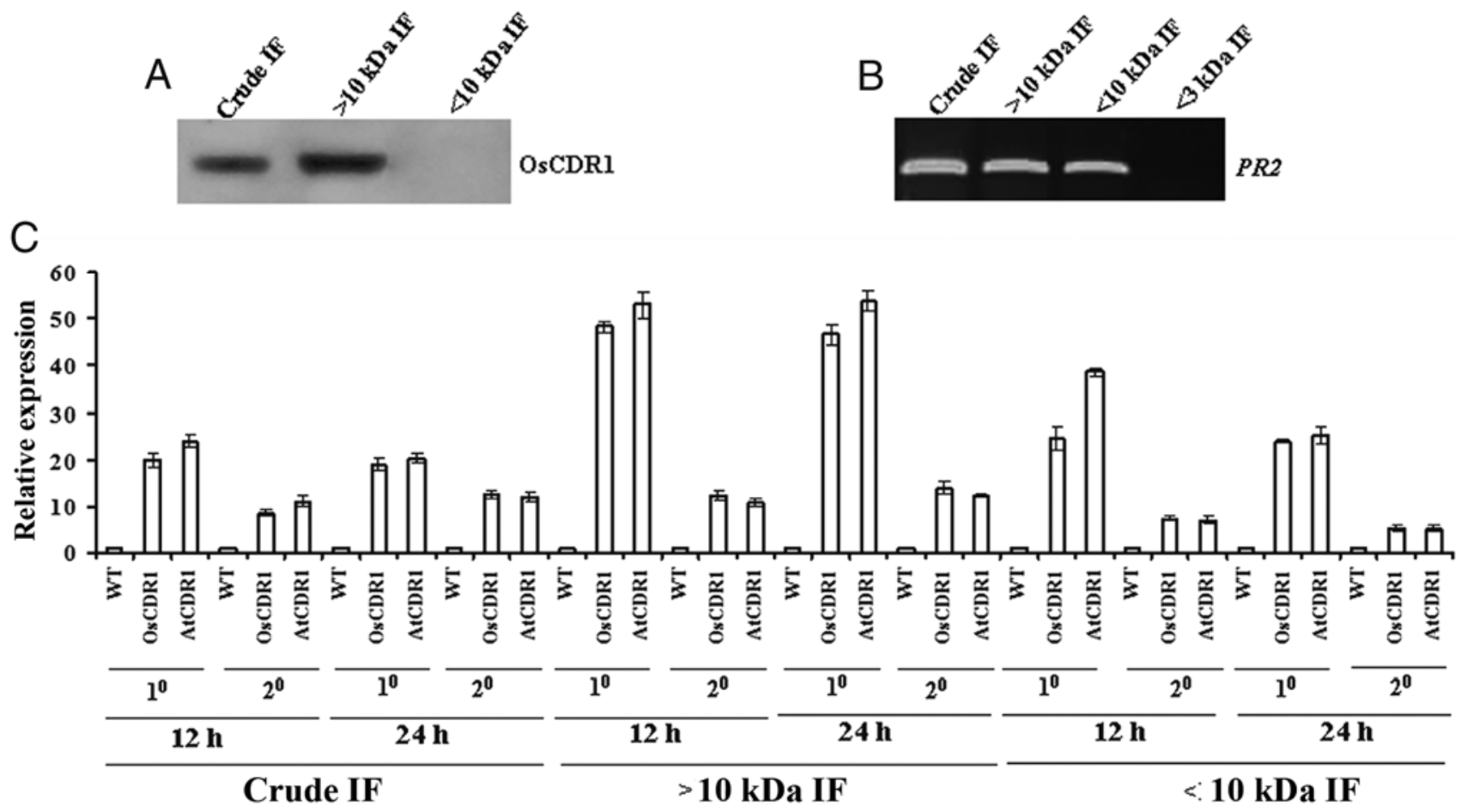

Fig. 7. Elicitor activity of OsCDR1. A, Immunodetection of OsCDR1 in the crude intercellular fluids (IFs) and two fractions of the IFs from At17. B, Reverse-transcriptase polymerase chain reaction (PCR) analysis of OsCDRl expression in a wild-type (WT) Arabidopsis leaf infiltrated with crude IFs and three fractions of the IFs (high molecular weight [HMW] $>10 \mathrm{kDa}$ and low molecular weight [LMW] $<10 \mathrm{kDa}$ to $>3 \mathrm{kDa}$ and $<3 \mathrm{kDa}$ ). The elicitor in the LMW fraction has a molecular weight of 3 to $10 \mathrm{kDa}$. C, Responses of PR2 gene expression in a WT Arabidopsis leaf infiltrated with crude IFs and two fractions (HMW and LMW) of the IFs. The infiltrated primary $\left(1^{\circ}\right)$ and untreated secondary $\left(2^{\circ}\right)$ leaves were collected separately and subjected to quantitative PCR analysis. IFs of the AtCDR1-overexpressing plant was kept as a positive control. Bars represent mean \pm standard deviation. 
$\mu \mathrm{mol} \mathrm{m} \mathrm{m}^{-2} \mathrm{~s}^{-1}$ ) for 5 weeks, followed by growth under long-day conditions (16 h of light and $8 \mathrm{~h}$ of darkness) until they matured. Indica rice cv. Pusa Basmati 1 (PB 1) was maintained in the greenhouse $\left(28\right.$ and $23^{\circ} \mathrm{C}$, day and night, respectively). Treatments with BTH and JA (Sigma-Aldrich, St Louis) were performed as described previously (Delaney et al. 1994). For SA treatments, rice seedlings were dipped in $500 \mathrm{ml}$ of $3 \mathrm{mM}$ sodium salicylate with sterilized distilled water as a control.

\section{Plasmid constructions.}

OsCDRl was amplified by PCR from PAC clone P0509B06 using the primers $5^{\prime}$-ATGGCGGCCATGGCGCCTTCCTC-3' and 5'-CTAGGATGAGCCGGCGCAGTCGGCG-3'. The PCR product was gel purified and cloned into the EcoRV site of pBluescript $\mathrm{KS}^{+}$to obtain pKSOsCDRl and its sequence was verified. The $O s C D R l$ insert was excised using $X b a \mathrm{I}$ and $X h o \mathrm{I}$ and cloned into pRTdS vector digested with the same enzymes, creating plasmid pD35SOsCDR1. The 35SOsCDRl gene cassette was excised from pD35SOsCDRl using HindIII and was cloned into HindIII site of the binary vector pCAMBIA-1305.2 to create pD35SOsCDR1-T, which was mobilized into Agrobacterium tumefaciens strains LBA4404 and GV3101mp90 for rice and Arabidopsis transformation, respectively.

\section{OsCDR1 site-directed mutants.}

For the construction of $O s C D R 1$ mutants, pKSOsCDRl was used as a template for PCR. For D119N and D233N in which the aspartate residue at positions 119 or 233 was replaced by asparagine, mutation was carried out using the primers $5^{\prime}$ GCCATCGCCAAACACGGGCA-3' and 5'-CGGTAGCGGTTG TGCCCGT-3', respectively. The whole plasmid was amplified with Phusion DNA polymerase (Finnzymes, Espoo, Finland).
Following amplifications, the reaction product was digested with DpnI and transformed into Escherichia coli (DH5 $\alpha$ ). After confirming the mutations by DNA sequencing, mutated pKSOsCDRl was excised with HindIII and EcoRI and cloned into the binary vector pG0229 (Hellens et al. 2000) digested with the same enzymes, creating plasmid pG0229-D119N and pG0229-D233N. Constructs were mobilized into the A. tumefaciens $\mathrm{GV} 3101 \mathrm{mp} 90$ by electroporation.

\section{Sequence analysis.}

Similarity searches on nucleotide and amino acid sequences were carried out using BLAST at the National Center for Biotechnology Information GenBank database. A phylogenetic tree was constructed by the neighbor-joining method based on the genetic distance of the protein sequences by the Clustal $\mathrm{X}$ version 1.81 .

\section{Generation of transgenic plants.}

Transformation of Arabidopsis was performed using the floral dip method as described previously (Clough and Bent 1998). Rice calli were used for transformation as described by Hiei and associates (1994).

\section{RNA extraction, RT-PCR, and qPCR.}

Total RNA was extracted using Trizol Reagent (Invitrogen Life Technologies, San Diego, CA, U.S.A.) as per the manufacturer's instructions. First-strand cDNA was synthesized from $1 \mu \mathrm{g}$ of total RNA using superscript II reverse transcriptase (Invitrogen Life Technologies) under conditions recommended by the manufacturers and used as a template for RTPCR and qPCR. qPCR was conducted using SYBR Green dye either on a LightCycler system for real-time PCR (Roche Applied Science, Indianapolis, IN, U.S.A.) or SYBR Green

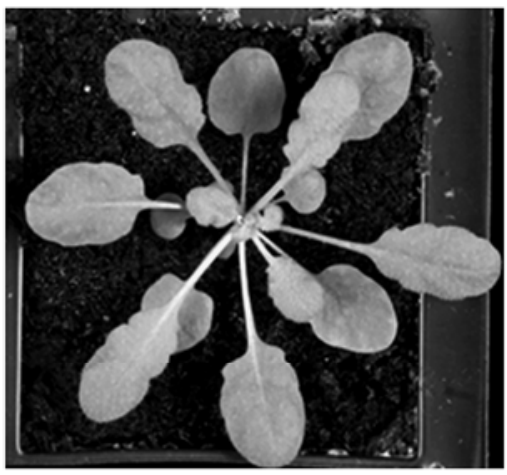

WT

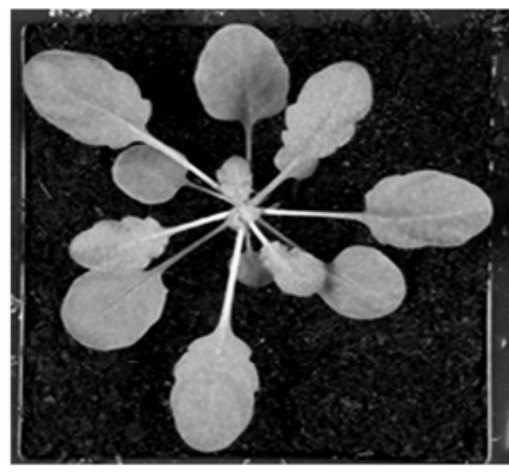

At3

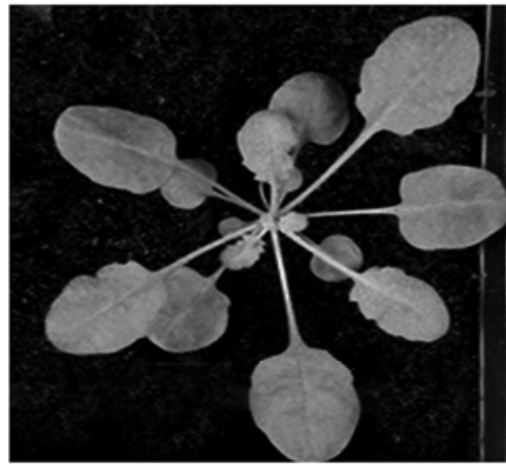

At6

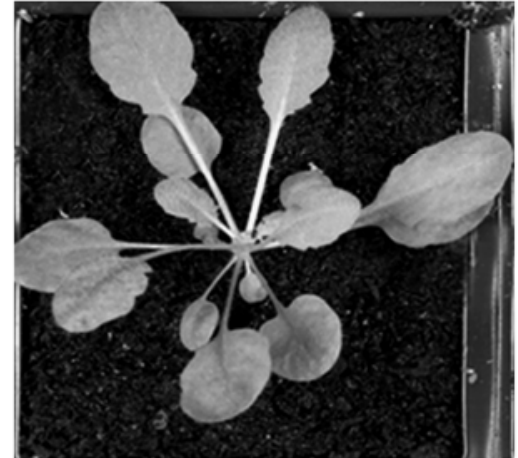

At8

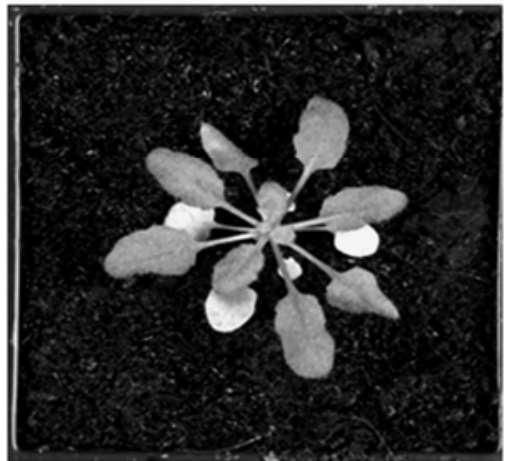

At17

Fig. 8. Phenotypes of OsCDR1:Arabidopsis lines. Transgenic Arabidopsis lines At3, At6, and At8 appeared normal whereas line At17 showed growth retardation compared with the wild type (WT). The pictures were taken 4 weeks after sowing. 
JumpStart (Sigma-Aldrich) in a DNA engine Opticon2 (MJ Research, Waltham, MA, U.S.A.) following the manufacturer's instructions. Values were normalized using actin as the internal reference, and fold change in the expression level was calculated (Livak and Schmittgen 2001).

\section{Indirect immunolocalization.}

Indirect immunolocalization studies were performed as described by Patkar and Chattoo (2006).

\section{Extraction and quantification of SA.}

SA was extracted and analyzed as described (Raskin et al. 1989). Chromatographic separation was achieved by $0.1 \%$ formic acid in water versus $0.1 \%$ formic acid in methanol using a

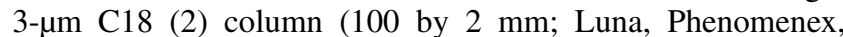
Cheshire, U.K.) operated at $23^{\circ} \mathrm{C}$, with a $250-\mu \mathrm{l} / \mathrm{min}$ flow rate. SA concentrations were measured using negative electrospray mass spectrometry on a single quadrupole liquid chromatography-mass spectrometry system (Agilent 1100), measuring in single-ion mode, 137.0 and $141.1 \mathrm{~m} / \mathrm{z}$, fragmentor voltage of $70 \mathrm{~V}$; and the spray chamber conditions were 10 liter min $^{-1}$ drying gas at $350^{\circ} \mathrm{C}, 25$ psi nebulizer pressure, 3,500-V capillary voltage.

\section{Detection of reactive oxygen intermediate.}

DAB staining was performed as described previously (Alvarez et al. 1998).

\section{Immunoblot analysis.}

Anti-OsCDR1 polyclonal antibodies were raised against a synthetic peptide (SSAAAPTTQFDPSRSSTYG). Immunoblotting was performed according to standard protocols (Sambrook et al. 1989). The resulting antibodies cross-reacted with the OsCDR1 product but showed no cross-reactivity with AtCDR1 product.

\section{Disease assays.}

For disease testing, the abaxial side of Arabidopsis leaves from 4- to 5-week-old plants were infiltrated using a 1-ml syringe with either $10 \mathrm{mM} \mathrm{MgCl}_{2}$ (mock) or $P$. syringae DC3000 $\left(10^{6} \mathrm{CFU} \mathrm{ml} \mathrm{m}^{-1}\right.$ in $\left.10 \mathrm{mM} \mathrm{MgCl}_{2}\right)$ as previously described (Cameron et al. 1994). H. arabidopsidis assays were performed on 4-week-old plants by spraying with a conidial suspension $\left(4 \times 10^{4}\right.$ conidia ml ${ }^{-1}$ in sterile water) of $\mathrm{H}$. arabidopsidis isolate Noco 2 to run-off. Following inoculation, seedlings were incubated at $16^{\circ} \mathrm{C}$ and conidia were counted at 5 dpi. Inoculation with Alternaria brassicicola was done by applying $5 \mu \mathrm{l}$ of spore suspension $\left(1 \times 10^{6}\right.$ spores $\left.\mathrm{ml}^{-1}\right)$ in water on four leaves of 4-week-old plants. Inoculated plants were kept under a transparent cover to maintain high humidity and transferred to a growth chamber $\left(24^{\circ} \mathrm{C}, 12 \mathrm{~h}\right.$ of light and $12 \mathrm{~h}$ of darkness). Lesions that developed on inoculated leaves were measured at $5 \mathrm{dpi}$. An in planta $X$. oryzae pv. oryzae inoculation assay was done by the "scissors clip-inoculation" method (Kauffman et al. 1973). Plant infection assays with M. oryzae (isolate B157; international race IC9) were carried out as described before (Prasad et al. 2008).

\section{IF.}

Sterilized (10\% bleach, $20 \mathrm{~min}$ ) At17 Arabidopsis seed (approximately $10 \mathrm{mg}$ ) were grown in liquid MS medium in 250$\mathrm{ml}$ Ehrlenmeyer flasks at $100 \mathrm{rpm}$ for 2 weeks. Then, the medium was decanted and the seedlings were washed twice with sterile water and $100 \mathrm{ml}$ of sterile water was added to the flask and swirled overnight at $100 \mathrm{rpm}$. Following filtration through a 38- $\mu \mathrm{m}$ filter, the water, containing apoplastic solutes, was fractionated (10-kDa cut-off; Vivaspin 20; Sartorius, Goettingen,
Germany). The filtrate and the retentate were collected and labeled as LMW and HMW fractions, respectively. The LMW fraction was further fractionated using a 3-kDa cut-off filter.

\section{ACKNOWLEDGMENTS}

The present work was funded by the U.K. Biotechnology and Biological Sciences Research Council and by a grant from the Indo-UK Collaboration between the Department of Biotechnology, Ministry of Science and Technology, Government of India and the U.K. Government Global Opportunities Fund. We thank MAFF DNA Bank, National Institute of Agrobiological Sciences (NIAS), Japan for providing the PAC clone and L. Hill for assistance with SA assays.

\section{LITERATURE CITED}

Alvarez, M. E., Pennell, R. I., Meijer, P. J., Ishikawa, A., Dixon, R. A., and Lamb, C. 1998. Reactive oxygen intermediates mediate a systemic signal network in the establishment of plant immunity. Cell 92:773-784.

Bi, Y. M., Kenton, P., Mur, L., Darby, R., and Draper, J. 1995. Hydrogen peroxide does not function downstream of salicylic acid in the induction of PR protein expression. Plant J. 8:235-245.

Cameron, R. K., Dixon, R. A., and Lamb, C. J. 1994. Biologically induced systemic acquired resistance in Arabidopsis thaliana. Plant J. 5:715725.

Chen, Z., Ricigliano, J. W., and Klessig, D. F. 1993a. Purification and characterization of a soluble salicylic acid-binding protein from tobacco. Proc. Natl. Acad. Sci. U.S.A. 90:9533-9537.

Chen, Z., Silva, H., and Klessig, D. F. 1993b. Active oxygen species in the induction of plant systemic acquired resistance by salicylic acid. Science 262:1883-1886

Clough, S. J., and Bent, A. F. 1998. Floral dip: A simplified method for Agrobacterium mediated transformation of Arabidopsis thaliana. Plant J. 16:735-743.

Dangl, J. L., and Jones, J. D. G. 2001. Plant pathogens and integrated defence responses to infection. Nature 411:826-833.

Delaney, T. P., Uknes, S., Vernooij, B., Friedrich, L., Weymann, K., Negrotto, D., Gaffney, T., Gut-Rella, M., Kessmann, H., Ward, E., and Ryals, J. 1994. A central role of salicylic acid in plant disease resistance. Science 266:1247-1250.

Domsalla, A., and Melzig, M. F. 2008. Occurrence and properties of proteases in plant lattices. Planta Med. 74:699-711.

Durrant, W. E., and Dong, X. 2004. Systemic acquired resistance. Annu. Rev. Phytopathol. 42:185-209.

Epple, P., Apel, K., and Bohlmann, H. 1997. Overexpression of an endogenous thionin enhances resistance of Arabidopsis against Fusarium oxysporum. Plant Cell 9:509-520.

Gaffney, T., Friedrich, L., Vernooij, B., Negrotto, D., Nye, G., Uknes, S., Ward, E., Kesmann, H., and Ryals, J. 1993. Requirement of salicylic acid for induction of systemic acquired resistance. Science 261:754756.

Ganesan, V., and Thomas, G. 2001. Salicylic acid response in rice: Influence of salicylic acid on $\mathrm{H}_{2} \mathrm{O}_{2}$ accumulation and oxidative stress. Plant Sci. 160:1095-1106.

Gorlach, J., Volrath, S., Knauf-Beiter, G., Hengy, G., Beckhove, U., Kogel, K. H., Oostendorp, M., Staub, T., Ward, E., Kessmann, H., and Ryals, J. 1996. Benzothiadiazole, a novel class of inducers of systemic acquired resistance, activates gene expression and disease resistance in wheat Plant Cell 4:629-643.

Grant, M., and Lamb, C. 2006. Systemic immunity. Curr. Opin. Plant Biol. 9:414-420.

Gupta, V., Willits, M. G., and Glazebrook, J. 2000. Arabidopsis thaliana EDS4 contributes to salicylic acid (SA)-dependent expression of defense responses: Evidence for inhibition of jasmonic acid signaling by SA. Mol. Plant-Microbe Interact. 13:503-511.

Hellens, R. P., Edwards, E. A., Leyland, N. R., Bean, S., and Mullineaux, P. M. 2000. pGreen: A versatile and flexible binary Ti vector for Agrobacterium-mediated plant transformation. Plant Mol. Biol. 42:819-832.

Hiei, Y., Ohta, S., Komari, T., and Kumashiro, T. 1994. Efficient transformation of rice (Oryza sativa L.) mediated by Agrobacterium and sequence analysis of the boundaries of the T-DNA. Plant J. 6:271-282.

Jach, G., Görnhardt, B., Mundy, J., Logemann, J., Pinsdorf, E., Leah, R., Schell, J., and Maas, C. 1995. Enhanced quantitative resistance against fungal disease by combinatorial expression of different barley antifungal proteins in transgenic tobacco. Plant J. 8:97-109.

Jia, Y., McAdams, S. A., Bryan, G. T., Hershey, H. P., and Valent, B. 2000. Direct interaction of resistance gene and avirulence gene products confers rice blast resistance. EMBO (Eur. Mol. Biol. Organ.) J. 19:4004- 
4014

Kauffman, H. E., Reddy, A. P. K., Hsieh, S. P. V., and Marca, S. D. 1973. An improved technique for evaluation of resistance of rice varieties to Xanthomonas oryzae. Plant Dis. Rep. 57:537-541.

Kunkel, B. N., and Brooks, D. M. 2002. Cross talk between signaling pathways in pathogen defense. Curr. Opin. Biotechnol. 5:325-331.

Li, D., Liu, H., Zhang, H., Wang X., and Song, F. 2008. OsBIRH1, a DEAD-box RNA helicase with functions in modulating defence responses against pathogen infection and oxidative stress. J. Exp. Bot. 59:2133-2146.

Livak, K. J., and Schmittgen, T. D. 2001. Analysis of relative gene expression data using real-time quantitative PCR and the $2^{-\Delta \Lambda C T}$ method. Methods 25:402-408.

Mitsuhara, I., Iwai, T., Seo, S., Yanagawa, Y., Kawahigasi, H., Hirose, S., Ohkawa, Y., and Ohashi, Y. 2008. Characteristic expression of twelve rice $P R 1$ family genes in response to pathogen infection, wounding, and defense-related signal compounds (121/180). Mol. Genet. Genomics 279:415-427.

Nakai, K., and Kanehisa, M. 1992. A knowledge base for predicting protein localisation sites in eukaryotic cells. Genomics 14:897-911.

Orth, K., Xu, Z., Mudgett, M. B., Bao, Z. Q., Palmer, L. E., Bliska, J. B., Mangel, W. F., Staskawicz, B., and Dixon, J. E. 2000. Disruption of signaling by Yersinia effector YopJ, a ubiquitin-like protein protease. Science 290:1594-1597.

Patkar, R. N., and Chattoo, B. B. 2006. Transgenic indica rice expressing ns-LTP like protein shows enhanced resistance to both fungal and bacterial pathogens. Mol. Breed. 17:159-171.

Penninckx, I. A. M. A., Eggermont, K., Terras, F. R. G., Thomma, B. P. H. J., Samblanx, G. W. D., Buchala, A., Metraux, J. P., Manners, J. M., and Broekaert, W. F. 1996. Pathogen-induced systemic activation of a plant defensin gene in Arabidopsis follows a salicylic acid-independent pathway. Plant Cell 8:2309-2323.

Prasad, B. D., Jha, S., and Chattoo, B. B. 2008. Transgenic indica rice expressing Mirabilis jalapa antimicrobial protein (Mj-AMP2) shows enhanced resistance to the rice blast fungus Magnaporthe oryzae. Plant Sci. 175:364-371

Raskin, I., Turner, I. M., and Melander, W. R. 1989. Regulation of heat production in the inflorescences of an Arum lily by endogenous salicylic acid. Proc. Natl. Acad. Sci. U.S.A. 86:2214-2218.

Sambrook, J., Fritch, E., and Maniatis, T. 1989. Molecular Cloning: A Laboratory Manual, 2nd ed. Cold Spring Harbor Laboratory Press,
Cold Spring Harbor, NY, U.S.A.

Shao, F., Merritt, P. M., Bao, Z., Innes, R. W., and Dixon, J. E. 2002. A Yersinia effector and a Pseudomonas avirulence protein define a family of cysteine proteases functioning in bacterial pathogenesis. Cell 109:575-588.

Silverman, P., Sesker, M., Kanter, D., Schweizer, P., Metraux, J.-P., and Raskin, I. 1995. Salicylic acid in rice. Plant Physiol. 108:633-639.

Simoes, I., and Faro, C. 2004. Structure and function of plant aspartic proteinases. Eur. J. Biochem. 271:2067-2075.

Spoel, S. H., Koornneef, A., Claessens, S. M. C., Korzelius J. P., Van Pelt, J. A., Mueller, M. J., Buchala, A. J., Métraux J.-P., Brown, R., Kazan, K., Van Loon, L. C., Dong, X., and Pieterse C. M. J. 2003. NPR1 modulates cross talk between salicylate- and jasmonate-dependent plant defense pathways through a novel function in the cytosol. Plant Cell 15:760-770.

Weigel, D., Ahn, J. H., Blázquez, M. A., Borevitz, J. O., Christensen, S K., Fankhauser, C., Ferrándiz, C., Kardailsky, I., Malancharuvil, E. J., Neff, M. M., Nguyen, J. T., Sato, S., Wang, Z. Y., Xia, Y., Dixon, R. A. Harrison, M. J., Lamb, C. J., Yanofsky, M. F., and Chory, J. 2000. Activation tagging in Arabidopsis. Plant Physiol. 122:1003-1013.

Xia, Y., Suzuki, H., Borevitz, J., Blount, J., Guo, Z., Patel, K., Dixon, R. A., and Lamb, C. 2004. An extracellular aspartic protease functions in Arabidopsis disease resistance signaling. EMBO (Eur. Mol. Biol. Organ.) J. 23:980-988.

Xiong, L., Lee, M. W., Qi, M., and Yang, Y. 2001. Cell signaling during cold, drought, and salt stress. Mol. Plant-Microbe Interact. 13:869-876.

$\mathrm{Xu}$, R., Song, F., and Zheng, Z. 2006. OsBISAMT1, a gene encoding Sadenosyl-L-methionine: Salicylic acid carboxyl methyltransferase, is differentially expressed in rice defense responses. Mol. Biol. Rep. 33:223-231.

Yang, Y., Shah, J., and Klessig, D. F. 1997. Signal perception and transduction in plant defence responses. Genes Dev. 11:1621-1639.

\section{AUTHOR-RECOMMENDED INTERNET RESOURCES}

European Molecular Biology Laboratory-European Bioinformatics Institute ClustalW webpage: www.ebi.ac.uk/clustralw

MEROPS peptidase database: merops.sanger.ac.uk

The National Center for Biotechnology Information BLASTP homepage: www.ncbi.nlm.nih.gov/blast 